\title{
Effects of Anaerobic Soil Disinfestation on Sclerotinia sclerotiorum in Paraguay
}

\author{
Andres D. Sanabria-Velazquez, ${ }^{1,2}$ Anna L. Testen, ${ }^{1}$ Guillermo A. Enciso, ${ }^{3}$ Laura C. Soilan, ${ }^{4}$ and Sally A. Miller ${ }^{1, t}$ \\ ${ }^{1}$ Department of Plant Pathology, Ohio Agricultural Research and Development Center, The Ohio State University, Wooster 44691, OH, U.S.A.; \\ ${ }^{2}$ Department of Phytopathology, Paraguayan Institute of Agricultural Technologies (IPTA), Caacupe, Paraguay; ${ }^{3}$ Department of Research and \\ Development, Paraguayan Center of Agrarian Technologies (CETAPAR), Alto Parana, Paraguay; and ${ }^{4}$ Area of Plant Protection, College of \\ Agricultural Sciences, National University of Asuncion (UNA), San Lorenzo, Paraguay
}

Accepted for publication 11 February 2019.

\begin{abstract}
The effects of anaerobic soil disinfestation (ASD) on Sclerotinia sclerotiorum sclerotia viability was tested in four field trials in Paraguay. Plots were amended with wheat bran (20.2 Mg/ha), molasses (10.1 Mg/ha), or wheat bran (20.2 Mg/ha) plus molasses (10.1 Mg/ha), saturated with water, and covered with black plastic mulch for 3 weeks. Control plots were not amended but were saturated and either covered (anaerobic control) or maintained uncovered (aerobic control). Tubes painted with iron oxide paint were placed in soils to assess soil reducing conditions. Sclerotia were buried $6 \mathrm{~cm}$ deep in treated and control soils along with temperature data loggers. After 3 weeks, the viability of sclerotia was significantly lower in all ASD-treated soils (4 to 52\%) compared with the aerobic control soil $(100 \%)$, regardless of the

carbon source used. Sclerotial viability was also significantly reduced compared with anaerobic controls at three sites, depending on the carbon source used. A significant negative correlation between soil reducing conditions and sclerotia viability was observed at all sites. Wheat bran and molasses are widely available and inexpensive in Paraguay, and ASD with these carbon sources provides smallholder South American vegetable farmers with a new option for sustainable management of Sclerotinia and potentially other soilborne pathogens.

Keywords: anaerobic soil disinfestation (ASD), Sclerotinia sclerotiorum, white mold, cultural practices, sustainable agriculture, vegetable crops
\end{abstract}

\section{Anaerobic Soil Disinfestation as a Sustainable Management Technique for Sclerotinia sclerotiorum in Paraguayan Soils}

One of the most economically important and widely distributed soilborne diseases in South America is white mold caused by the fungal plant pathogen $S$. sclerotiorum, causing yield losses in a wide range of crops (Durman et al. 2003; Lobo et al. 2000; Wrather et al. 1997). In Paraguay, white mold threatens high-value vegetable crops such as tomato, pepper, and lettuce (Arrúa and Aquino 2013). This disease causes wilting of plants, and as it progresses, cottony white mycelium is formed and sclerotia are produced on, in, and around infected plants. Diseased plants eventually die, returning the sclerotia to the soil and increasing the amount of inoculum (Bardin and Huang 2001).

White mold disease management can be quite challenging for farmers, given the wide host range of the pathogen that limits the effectiveness of crop rotation and the general lack of resistant varieties (Subbarao 1998). In addition, S. sclerotiorum sclerotia can

\section{${ }^{\dagger}$ Corresponding author: S. A. Miller; E-mail: miller.769@osu.edu}

Funding: Research support was provided by the Fulbright Association Foreign Student Program and state and federal funds appropriated to The Ohio State University, College of Food, Agricultural, and Environmental Sciences, Ohio Agricultural Research and Development Center.

The author(s) declare no conflict of interest.

(C) 2019 The American Phytopathological Society survive for more than 5 years in the soil without a host (Ben-Yephet et al. 1993). When environmental conditions are conducive (20 to $25^{\circ} \mathrm{C}$ and $93 \%$ humidity), sclerotia can produce apothecia in which ascospores are formed (Matheron and Porchas 2005). These ascospores can be blown by the wind and land on susceptible tissue, causing disease (Kohli et al. 1995). Plants may be directly infected by mycelia that germinated eruptively from sclerotia as well (Patterson and Grogan 1985).

Sclerotia are the primary source of inoculum and play the main role in the disease cycle of $S$. sclerotiorum, because epidemics caused by this pathogen are monocyclic (Abawi and Grogan 1979). Therefore, management practices targeted to reducing the viability and number of sclerotia will result in a significant reduction in disease intensity (Ben-Yephet 1988). However, sclerotial pathogens can be particularly difficult to manage because inoculum is heterogeneously distributed in the field and difficult to reach (Hao and Subbarao 2005). In addition, few products are currently available for management of white mold, and many of them provide inconsistent results (Fernando et al. 2004). For this reason, more sustainable and appropriate methods for South American smallholder farmers that can reduce the inoculum in the soil are required.

A promising soil disinfestation technique was developed simultaneously in Japan (Momma et al. 2013) and the Netherlands (Blok et al. 2000) in the late 1990s called anaerobic soil disinfestation (ASD). The ASD process involves the application of soil amendments such as molasses, seed brans, or cover crops into the soil. Once soil amendments are incorporated, the soil is saturated with water and covered with plastic mulch for a period of 3 to 
15 weeks (Momma et al. 2013). During this process, microorganisms break down the carbon sources, producing toxic compounds deleterious to pathogens (Huang et al. 2016b) and leading to temporary anaerobic conditions in the soil (Shennan et al. 2018).

Soil treatment using ASD has been shown to reduce the viability of pathogens that produce sclerotia, such as Sclerotium rolfsii (Shrestha et al. 2018), as well as reducing the viability of microsclerotia of Verticillium dahliae (Goud et al. 2004; Wei et al. 2016) and Macrophomina phaseolina (Rosskopf et al. 2014). In addition, Rhizoctonia solani was significantly suppressed in soils treated with ASD regardless of amendment type, compared with a nonamended control (Huang et al. 2016a). However, Butler et al. (2014) reported that carbon source rates less than $1 \mathrm{mg}$ of carbon per gram of soil at moderate soil temperatures did not reduce the viability of $S$. sclerotiorum sclerotia or Fusarium root rot of common bean compared with the nontreated control. This suggests that ASD treatments have different effects on plant pathogens depending on the type and amount of carbon source used. Furthermore, the effectiveness of the disinfestation may vary considerably depending on environmental conditions and soil types (Testen and Miller 2018).

In Paraguay, environmental conditions and dominant soil types (Oxisols) (Amado and Eltz 2008) are different from those found in areas of the world in which ASD has been conducted previously (Shrestha et al. 2016). The humid tropical climate of the southeastern region is quite different from the more temperate climate in which ASD was tested previously for control of $S$. sclerotiorum (Thaning and Gerhardson 2001). In these tropical conditions, soils are likely to experience higher temperatures and moisture during summer (Amado and Eltz 2008), which could potentially improve ASD performance.

ASD appears to be a promising management technique for smallholder farmers in developing countries. However, before recommending this management practice, it is necessary to carry out trials in tropical soils with carbon sources locally available. The main objective of this study was to evaluate the effects of ASD using different carbon sources (molasses, wheat bran, and the combination of molasses and wheat bran) on S. sclerotiorum sclerotia under field conditions at four different sites in Paraguay. We evaluated the effect of ASD on soil temperature, quantified soil surface $\mathrm{CO}_{2}$ concentration for each carbon source during ASD, quantified soil reducing conditions during ASD, and evaluated the effects of ASD carbon sources (alone and combined) on sclerotia viability.

\section{ASD Treatments}

The experiments were performed at four different sites in the southern region of Paraguay (Fig. 1): Paraguayan Center of Agrarian Technologies (CETAPAR), Paraguayan Institute of Agrarian Technologies (IPTA), National University of Asuncion (UNA), and a smallholder farm. The characteristics of the sites are shown in Table 1; three of the locations were research institutions and one a small vegetable farm.

The experimental period was from December 2017 to January 2018. The trials were laid out in a Latin square design with five replications for each treatment with plots of $1 \mathrm{~m}$ by $1 \mathrm{~m}$ with a buffer zone of $1 \mathrm{~m}$ between the rows. Treatments were wheat bran (20.2 $\mathrm{Mg} / \mathrm{ha}$ ), molasses (10.1 Mg/ha), and wheat bran (20.2 Mg/ha) plus molasses $(10.1 \mathrm{Mg} / \mathrm{ha})$, and controls were nonamended and saturated and were either covered (anaerobic control) or uncovered (aerobic control) (Testen and Miller 2019). Carbon sources were manually incorporated into the soil with agricultural tools to a depth of $15 \mathrm{~cm}$. Molasses was diluted in tap water (1:2), thoroughly mixed, and applied with watering cans. Following amendment incorporation, fields were irrigated overnight using impulse sprinklers (Tramontina, Lambare, Central, Paraguay). As described by Momma et al. (2013), when the soil reached field capacity, plots were covered with black plastic mulch ( $1.5 \mathrm{~mm}$ thickness), making sure the edges were tightly sealed to avoid gas exchange with the environment (Fig. 2). Plots remained covered for 3 weeks, at which time the plastic mulch was removed and evaluations were made.

\section{Data Collection and Analysis}

The experimental designs used for data collection during the ASD trials are described in Table 2. Analysis of variance was used to analyze the data, and treatment means were compared using Tukey's honestly significant difference with a $5 \%$ family-wise error rate. Statistical analyses were carried out in $\mathrm{R}$ version 3.4.4 ( $\mathrm{R}$ Core Team 2018) using statistical packages agricolae (de Mendiburu 2015) and epiR (Stevenson et al. 2015). Data were analyzed separately by location, except for soil temperature, for which data were pooled. For all studies, normality of distributions was checked before analysis, and data were transformed using arcsine square root if appropriate. Nontransformed means and standard deviations were reported. Relationships between soil reducing conditions, measured as percentage of paint removed from indicator of reduction in soil (IRIS) tubes, and sclerotia viability were evaluated using correlation analysis at $P<0.05$. Pearson $(r)$ coefficients were reported when the correlation was significant.

\section{Soil Temperatures During ASD}

Soil temperatures were monitored using Hobo pendant data loggers (Onset Computer Co., Bourne, MA). Data loggers were wrapped in latex to avoid direct contact with the soil and placed

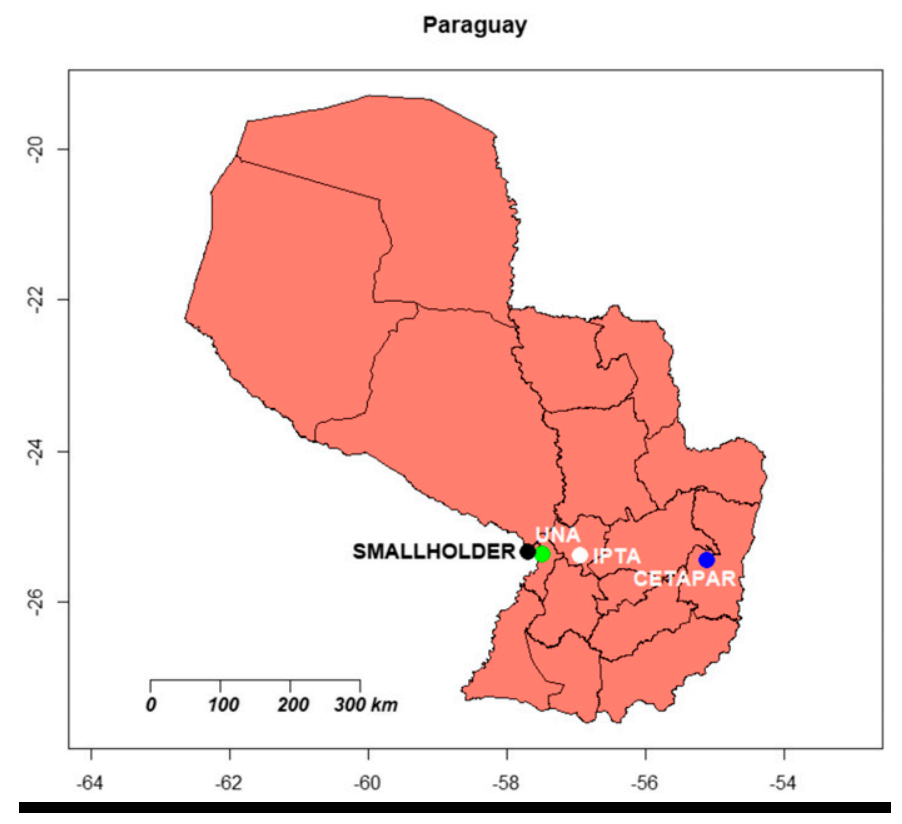

FIGURE 1

Experimental sites for anaerobic soil disinfestation trials in Paraguay. CETAPAR = Paraguayan Center of Agrarian Technologies; IPTA = Paraguayan Institute of Agrarian Technologies; UNA = National University of Asuncion; and smallholder $=$ smallholder farm 
$6 \mathrm{~cm}$ deep in the center of the plots before covering with plastic mulch. Five data loggers were used in each location (one per treatment). Temperature readings were taken every $30 \mathrm{~min}$ for 3 weeks, and mean temperatures were reported.

The effect of location as a blocking factor was significant $(P=$ 0.0001). At CETAPAR, the mean soil temperature across treatments was $30^{\circ} \mathrm{C}$, and in UNA the mean temperature was $30.2^{\circ} \mathrm{C}$.
The mean soil temperature for IPTA was the $30.9^{\circ} \mathrm{C}$, whereas at the smallholder farm it was $32.2^{\circ} \mathrm{C}$.

Mean soil temperatures across all four sites differed significantly by carbon source $(P=0.0001)$ during the ASD trials. Significantly lower mean soil temperatures were observed in aerobic control plots $\left(29.5^{\circ} \mathrm{C}\right.$ ) than in the anaerobic control and ASD-treated plots (Fig. $3)$. Mean soil temperatures in wheat bran-amended $\left(31.6^{\circ} \mathrm{C}\right)$ and

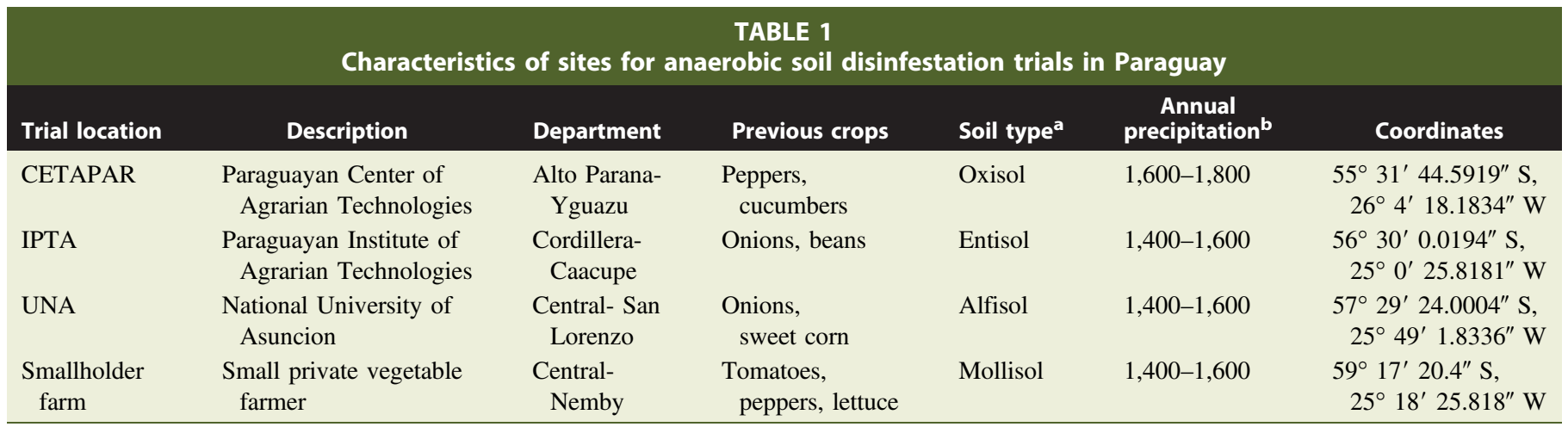

a USDA soil taxonomy classification.

${ }^{\mathrm{b}}$ Millimeters.

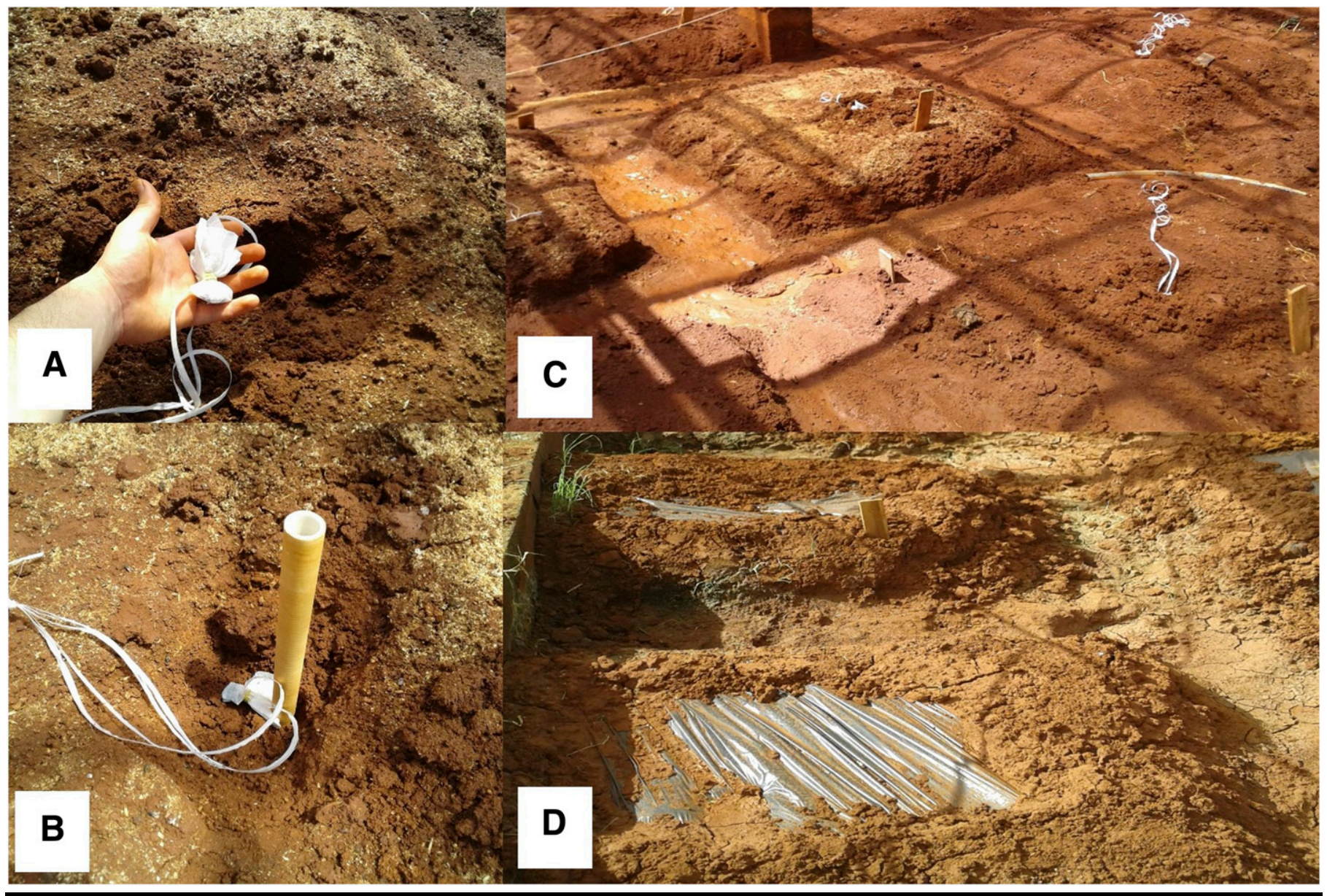

FIGURE 2

Anaerobic soil disinfestation (ASD) trial setup in Paraguay. A, Packets containing 10 sclerotia of Sclerotinia sclerotiorum were placed $6 \mathrm{~cm}$ deep in the center of soil beds. B, Indicator of reduction in soil (IRIS) tubes were placed in the center of soil beds to measure anaerobic conditions during the soil treatment. C, Different carbon sources and their combinations were applied and mixed into the beds. D, Soil beds were saturated with water and covered with black plastic, and edges were sealed with soil to trap gases produced during ASD. 
wheat bran plus molasses-amended $\left(31.9^{\circ} \mathrm{C}\right)$ plots were significantly higher than in anaerobic control plots $\left(30.2^{\circ} \mathrm{C}\right)$. The mean soil temperature in plots amended with molasses alone was similar to temperatures in the anaerobic control and wheat bran-amended plots and was significantly lower than the temperature of plots amended with wheat bran plus molasses.

\section{Soil Reducing Conditions During ASD}

The development of anaerobic conditions in soils can be measured using iron oxide-painted tubes to indicate extent of reducing conditions in soil (Rabenhorst 2010). The reduction of $\mathrm{Fe}$ (III) to Fe (II) during anaerobic conditions causes the paint to become soluble, allowing the quantification of areas where paint was removed from the tube (Castenson and Rabenhorst 2006). One IRIS tube $(30 \mathrm{~cm}$ long, $1.27 \mathrm{~cm}$ diameter polyvinyl chloride piping) was inserted into a guide hole in the center of each plot. At the end of the field trials, tubes were removed and washed carefully with tap water to remove soil debris. Areas where the paint was removed were quantified using ImageJ (National Institutes of Health, Bethesda, MD).

Only low levels ( 0 to $11 \%$ ) of iron oxide paint were removed from IRIS tubes from control plots across all four sites, and no differences in the percentage of paint removed were observed between tubes placed in either aerobic or anaerobic control soils (Fig. 4). The effects of blocking factors were not significant for any site. At three sites out of four (CETAPAR, IPTA, and smallholder farm), iron oxide paint removal was significantly higher for IRIS tubes placed in ASD-treated soils regardless of the carbon source compared with the aerobic control. However, iron oxide paint removal from IRIS tubes placed in soils amended with molasses and subjected to ASD did not differ significantly from paint removal from tubes placed in aerobic and anaerobic control plots at the UNA site (Fig. 4). The percentage of paint loss on IRIS tubes was not significantly different among ASD-treated soils regardless of the carbon source at three of four sites (CETAPAR, IPTA, and UNA). At the smallholder farmer site, IRIS tube paint removal was significantly lower in soils amended with wheat bran alone compared with those amended with wheat bran plus molasses (Fig. 4).

\section{Carbon Dioxide Concentration After ASD}

Soil surface carbon dioxide concentrations were measured using Dräger tubes (Dräger Safety, Lübeck, Germany). Soil air samples were taken from the center of the beds by making small holes in the middle of the plastic mulch and carefully introducing the Dräger tubes to avoid air exchange with the environment. Soil air was drawn through the Dräger tube once using a 100-ml syringe. A calibration scale of $\mathrm{CO}_{2}$ percent printed on the side of each tube allowed the measurement of the length of coloration showing the $\mathrm{CO}_{2}$ percentage by volume of sampled air (Hamada and Tanaka 2001).

Soil air $\mathrm{CO}_{2}$ concentrations differed significantly among treatments in all four sites (Fig. 5). The effect of blocking was not significant for any site. Significantly lower concentrations of $\mathrm{CO}_{2}$ were detected in aerobic control soils ( 0.18 to $0.56 \%$ in vol.) than in plastic covered soils (with or without amendment) at three of four sites (CETAPAR, UNA, and smallholder farm). Significant differences in $\mathrm{CO}_{2}$ production were not observed at the IPTA site between the aerobic and anaerobic controls. Soil $\mathrm{CO}_{2}$ concentrations ranged from 2.3 to $2.8 \%$ in anaerobic control plots. At every site, $\mathrm{CO}_{2}$ concentration was higher in ASD plots amended with wheat bran plus molasses (5.5 to $6 \%$ in vol.) than in the anaerobic control plots. The concentration of $\mathrm{CO}_{2}$ in plots amended with molasses alone was similar to that of the anaerobic control in three of four sites (CETAPAR, smallholder farmer, and IPTA); $\mathrm{CO}_{2}$ concentration in plots amended with molasses alone was higher than in the anaerobic control at the UNA site. The $\mathrm{CO}_{2}$ concentration in ASD-treated plots amended with wheat bran alone was only higher than in the anaerobic control at CETAPAR. No differences in soil $\mathrm{CO}_{2}$ concentration were observed between soils treated with ASD using molasses alone (3.5 to 5.3\% in vol.) or wheat bran alone (3.3 to $4.5 \%$ in vol.) at any site (Fig. 5).

\section{Effect of ASD on Sclerotia Viability of S. sclerotiorum}

The isolate FCQ40-SCSCCOPI16 of S. sclerotiorum isolated from a pepper production field in Paraguay was used in the field trials (Insaurralde et al. 2017). To produce sclerotia, potato tubers

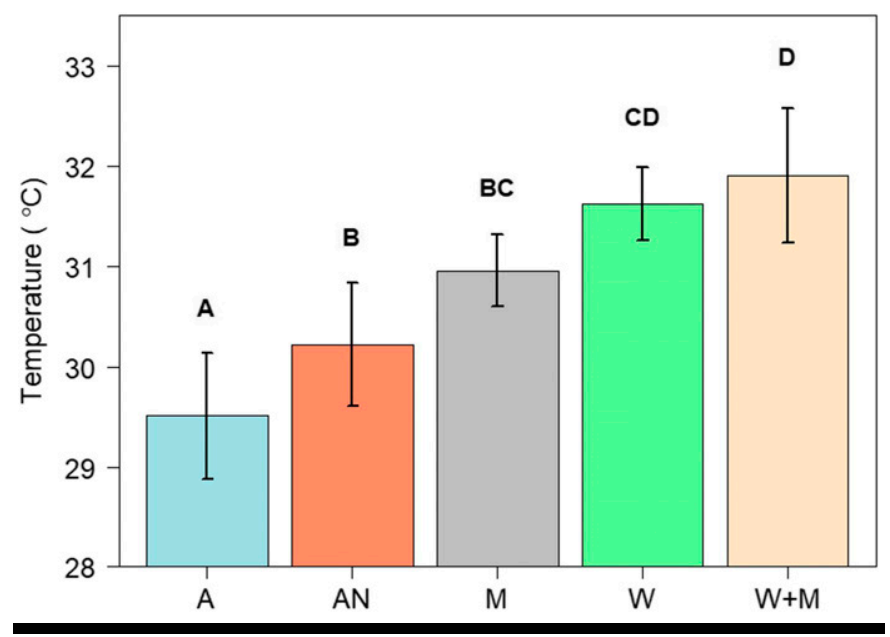

FIGURE 3

Mean soil temperatures over 3 weeks of anaerobic soil disinfestation (ASD) treatment with different carbon sources at four sites in Paraguay. Error bars indicate standard deviations with four replicates over four sites, and means indicated by different letters are significantly different according to Tukey's test $(P=0.0001) . \mathrm{A}=$ aerobic control (nonamended, saturated, noncovered); AN = anaerobic control (nonamended, saturated, plastic covered); $\mathrm{M}=$ molasses amended (10.1 Mg/ha); $\mathrm{W}=$ wheat bran amended $(20.2 \mathrm{Mg} / \mathrm{ha})$; and $\mathrm{W}+\mathrm{M}=$ wheat bran (20.2 Mg/ha) plus molasses (10.1 Mg/ha) amended.

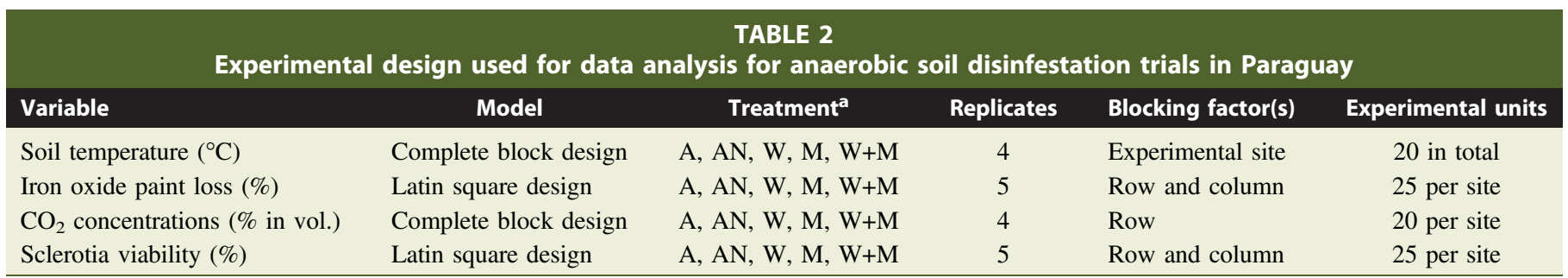

${ }^{\mathrm{a}} \mathrm{A}=$ aerobic control (nonamended, saturated, noncovered); $\mathrm{AN}=$ anaerobic control (nonamended, saturated, plastic covered); $\mathrm{M}=$ molasses amended $(10.1 \mathrm{Mg} / \mathrm{ha}) ; \mathrm{W}=$ wheat bran amended $(20.2 \mathrm{Mg} / \mathrm{ha})$; and $\mathrm{W}+\mathrm{M}=$ wheat bran $(20.2 \mathrm{Mg} / \mathrm{ha})$ plus molasses $(10.1 \mathrm{Mg} / \mathrm{ha}) \mathrm{amended}$. 
were peeled and cut into round slices, placed in glass Petri plates, and autoclaved once for $20 \mathrm{~min}$. Agar plugs from the margins of 3day-old $S$. sclerotiorum cultures were removed and placed on the autoclaved potato slices, and plates were incubated at room temperature for 4 weeks. Sclerotia were separated from the potato pieces, dried, and stored at room temperature until further use (Matheron and Porchas 2005).

Mesh packets containing 10 sclerotia of S. sclerotiorum were placed $6 \mathrm{~cm}$ deep in the center of each plot prior to soil saturation.
Once ASD treatment concluded, the sclerotia in the mesh packets were washed with tap water and dried for $24 \mathrm{~h}$. Sclerotia were then surface disinfested with a solution of $70 \%$ ethanol (60 s) and another wash with $5 \%$ sodium hypochlorite $(60 \mathrm{~s})$, followed by a triple rinse in sterile distilled water (60 s each). Neon-blue potato dextrose agar (PDA) medium, which is PDA amended with 100 ppm of rifampicin and $100 \mathrm{ppm}$ of bromophenol blue, was prepared to assess the viability of sclerotia. This medium is semiselective for detection of Sclerotinia spp. and changes color from blue to yellow as a result of

\section{CETAPAR}

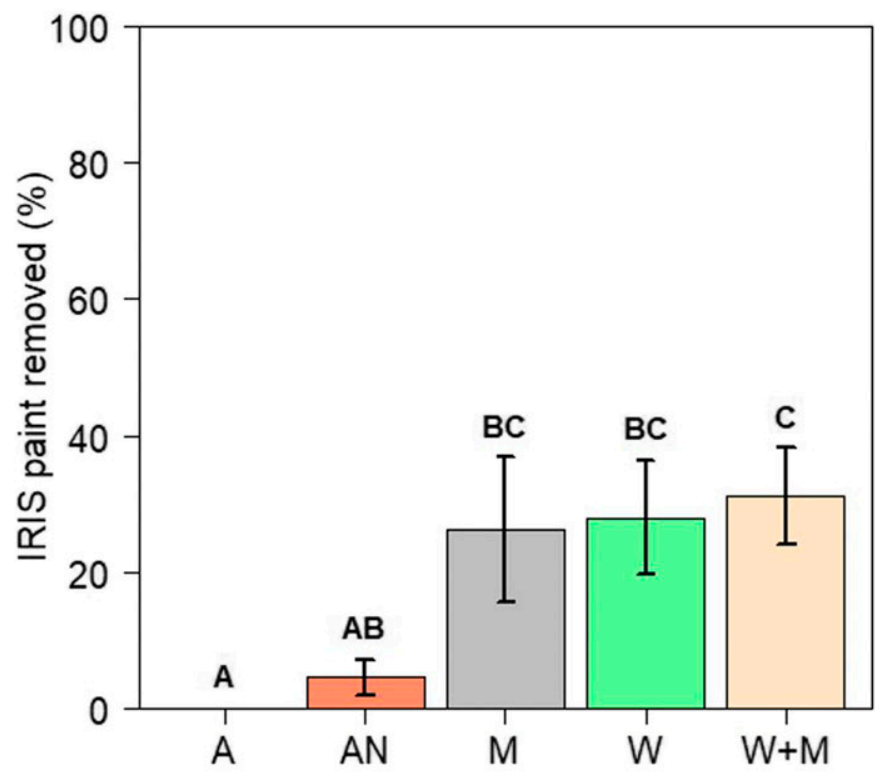

IPTA

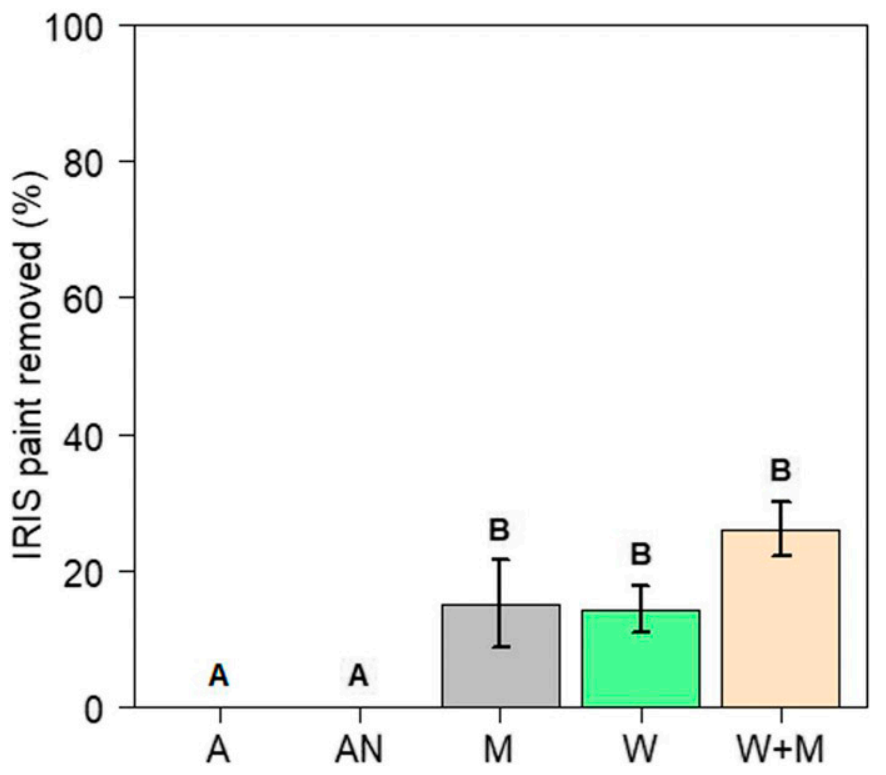

\section{Smallholder}

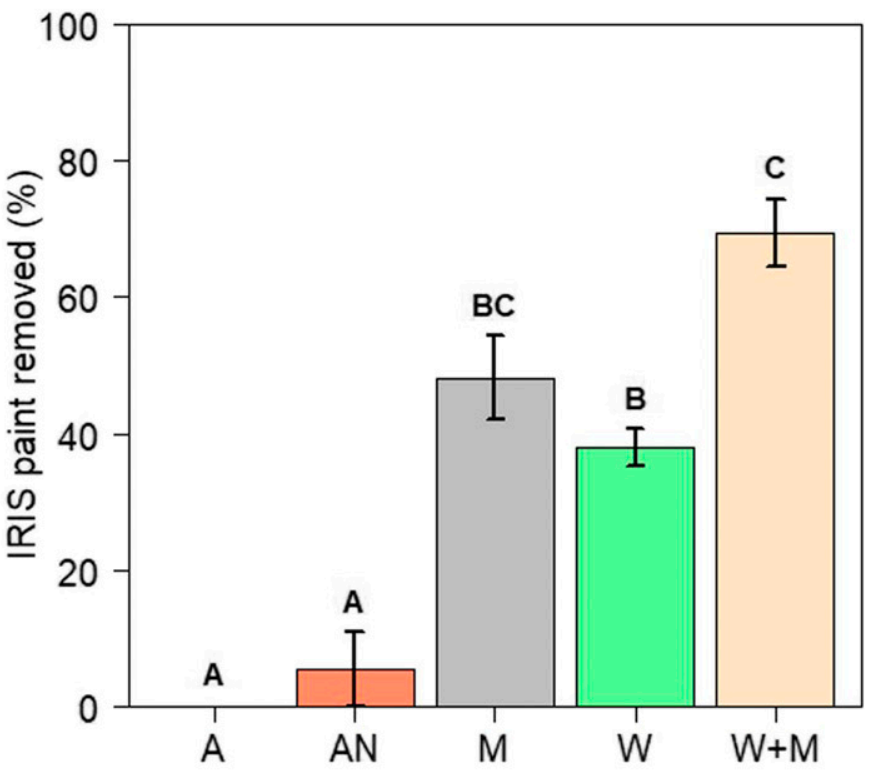

UNA

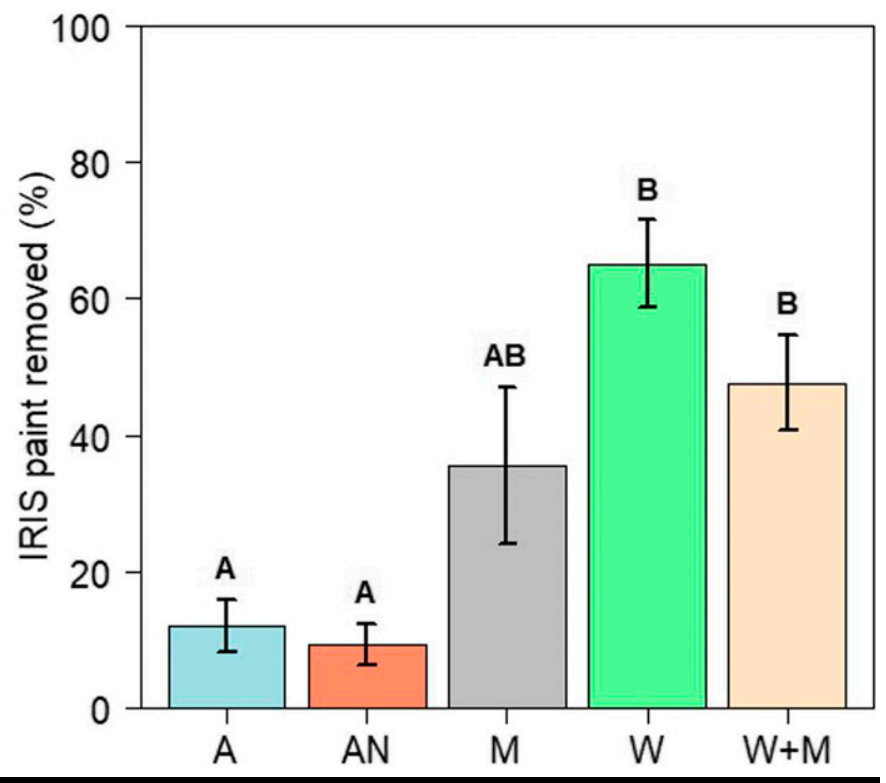

FIGURE 4

Indicator of reduction in soil (IRIS) iron oxide paint removal percentage during anaerobic soil disinfestation treatment with different carbon sources evaluated in four sites in Paraguay. Higher values of paint removal indicate higher anaerobicity. Error bars indicate standard deviation with five replicates, and means indicated by different letters are significantly different according to Tukey's test. CETAPAR $=$ Paraguayan Center of Agrarian Technologies $(P=0.0069)$; IPTA $=$ Paraguayan Institute of Agrarian Technologies ( $P=0.0001)$; UNA = National University of Asuncion $(P=0.0004)$; and smallholder $=$ smallholder farm $(P \leq 0.0001)$. $\mathrm{A}=$ aerobic control (nonamended, saturated, noncovered); $\mathrm{AN}=$ anaerobic control (nonamended, saturated, plastic covered); $\mathrm{M}=\mathrm{molasses}$ amended (10.1

$\mathrm{Mg} / \mathrm{ha}) ; \mathrm{W}=$ wheat bran amended $(20.2 \mathrm{Mg} / \mathrm{ha}) ;$ and $\mathrm{W}+\mathrm{M}=$ wheat bran $(20.2 \mathrm{Mg} / \mathrm{ha})$ plus molasses (10.1 Mg/ha) amended. 
oxalic acid production upon germination of viable sclerotia (Kawasaki and Machado 2013). Sclerotia were then placed on neon-blue PDA medium to assess their viability. Sclerotia producing white, fluffy mycelia and/or producing oxalic acid (changing the medium from blue to yellow) were considered viable.

All S. sclerotiorum sclerotia placed in aerobic control plots at all four sites were viable (Fig. 6) following the 3-week treatment period. Sclerotia viability ranged from 44 to $80 \%$ in anaerobic control plots. At the IPTA and UNA sites, significantly fewer sclerotia survived in anaerobic control plots than in aerobic control plots, whereas sclerotia survival did not differ significantly between

\section{CETAPAR}
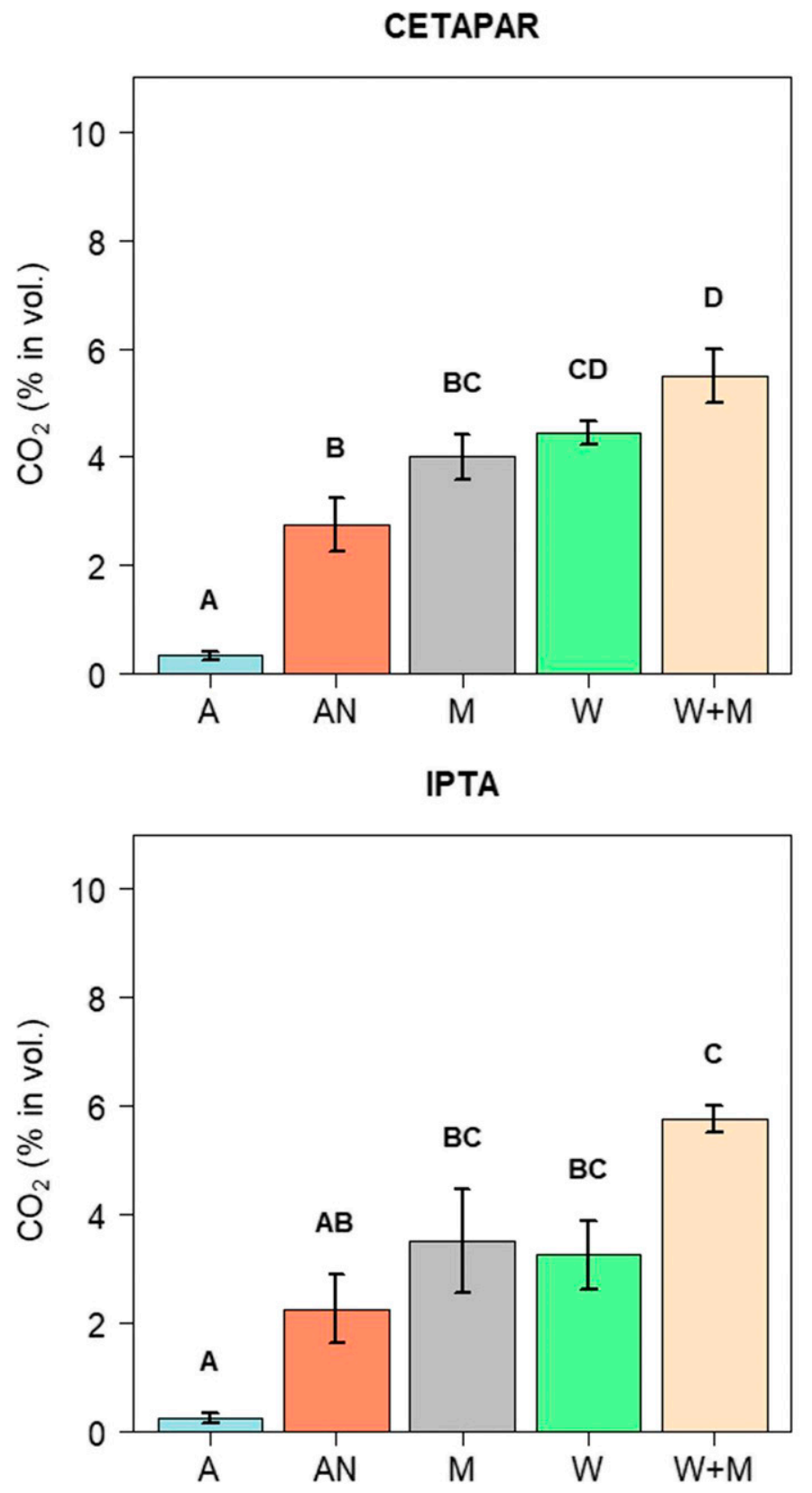

the two controls at the CETAPAR and smallholder farmer sites. Sclerotia viability was significantly reduced in soils treated with ASD regardless of the carbon source compared with the aerobic control at all experimental sites (Fig. 6). Differences between carbon source effectiveness in reducing sclerotial survival were observed at two (UNA and smallholder farm) sites.

Viability ranged from 6 to $20 \%$ across sites for sclerotia recovered from ASD-treated soils amended with wheat bran alone or in combination with molasses, whereas for soils amended with molasses alone, viability ranged from 22 to $52 \%$. At three sites (CETAPAR, UNA, and IPTA), the viability of sclerotia removed

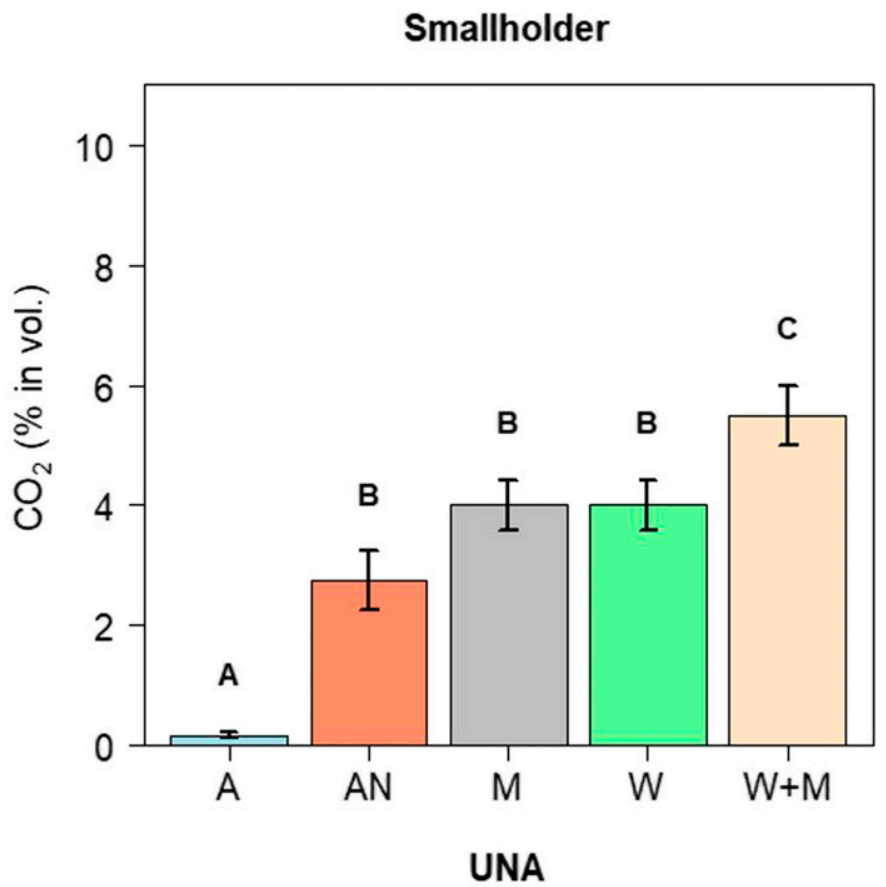

FIGURE 5

Soil $\mathrm{CO}_{2}$ concentration (\%) by volume measured after anaerobic soil disinfestation treatment at four sites in Paraguay. Error bars indicate standard deviations with five replicates, and means indicated by different letters are significantly different according to Tukey's test. CETAPAR $=$ Paraguayan Center of Agrarian Technologies $(P<0.0001)$; IPTA $=$ Paraguayan Institute of Agrarian Technologies $(P=0.0004) ;$ UNA $=$ National University of Asuncion $(P<0.0001)$; and smallholder $=$ smallholder farm $(P<0.0001) . A=$ aerobic control (nonamended, saturated, noncovered); $\mathrm{AN}=$ anaerobic control (nonamended, saturated, plastic covered); $\mathrm{M}=$ molasses amended (10.1 Mg/ha); $\mathrm{W}$ = wheat bran amended (20.2 Mg/ha); and $\mathrm{W}+\mathrm{M}$ = wheat bran (20.2 Mg/ha) plus molasses (10.1 Mg/ha) amended. 
from wheat bran-amended soils did not differ from that of sclerotia recovered from molasses-amended soils (Fig. 6). However, at the smallholder farm, significantly more viable sclerotia were recovered from plots amended with molasses alone than from wheat bran-amended plots. Sclerotia viability in soils treated with ASD using the combination of wheat bran plus molasses (4 to 20\%) did not differ significantly from viability in ASD-treated soils amended with wheat bran alone across all sites. Significantly more sclerotia recovered from molasses-amended plots were viable than those removed from plots amended with wheat bran plus molasses at two (UNA and smallholder farm) sites (Fig. 6).

A significant negative correlation was observed between sclerotia viability and soil reducing conditions as measured by iron oxide paint loss across the four sites with correlation values $(r)$ ranging from 0.58 to 0.76 (Fig. 7). Determination coefficients $\left(R^{2}\right)$ were lower than 0.60 for all of the sites. This negative relationship suggests that as soils become more anaerobic, the viability of the sclerotia of S. sclerotiorum decreases.

\section{CETAPAR}
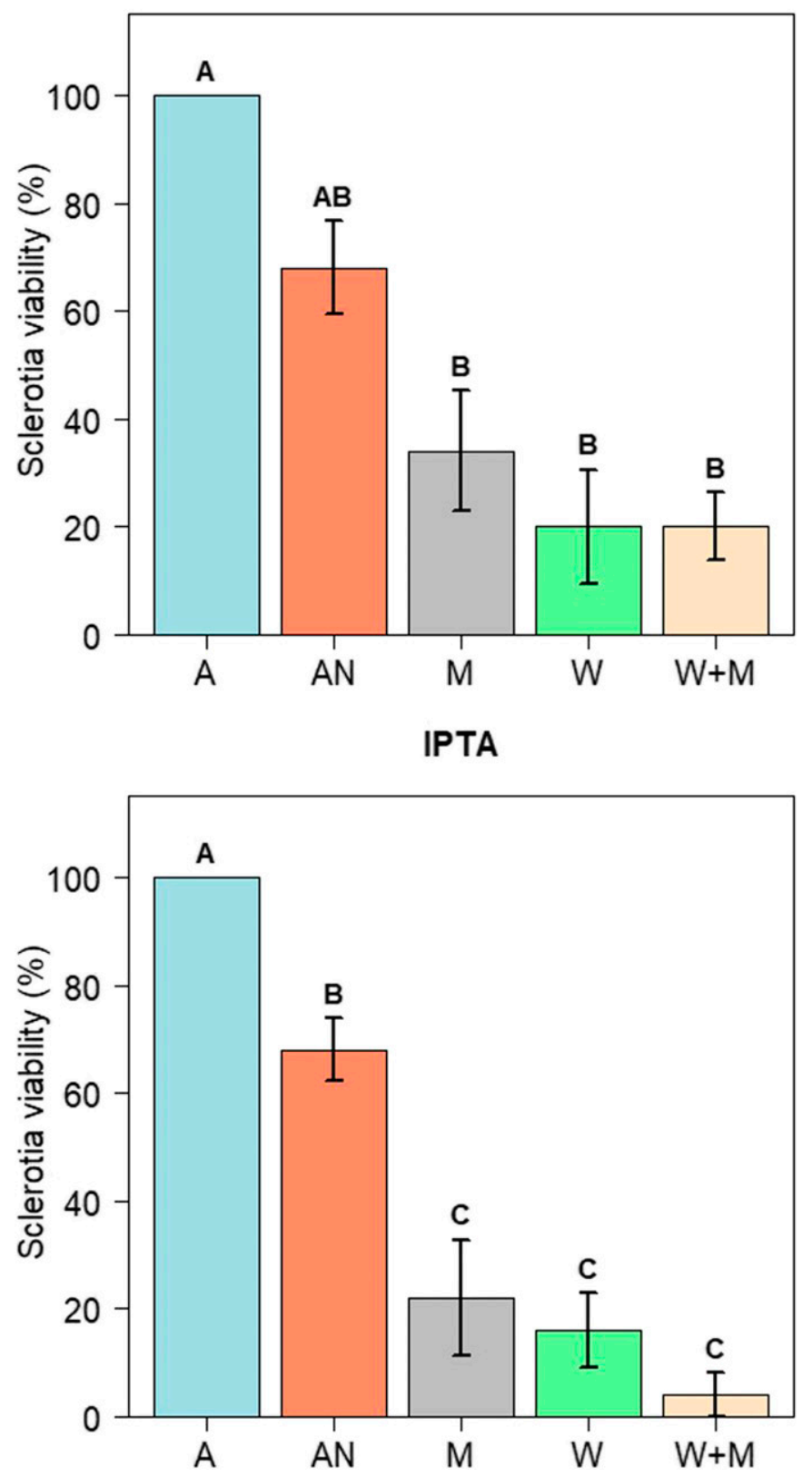

\section{Smallholder}
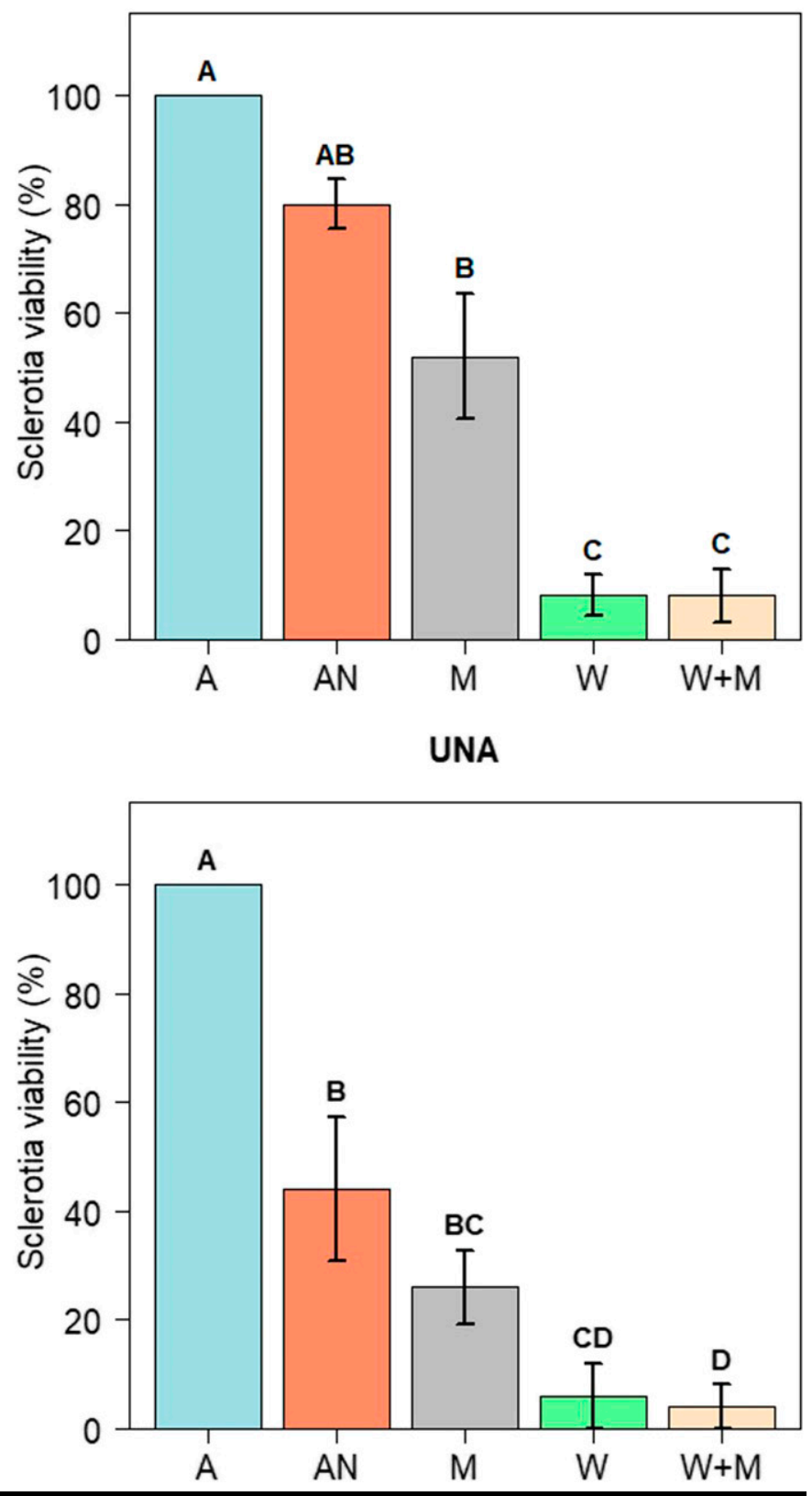

FIGURE 6

Effect of anaerobic soil disinfestation using different carbon sources on the viability of sclerotia of Sclerotinia sclerotiorum in four different sites in Paraguay. Error bars indicate standard deviation with five replicates, and means indicated by different letters are significantly different according to Tukey's test. CETAPAR $=$ Paraguayan Center of Agrarian Technologies $(P=0.0003)$; IPTA = Paraguayan Institute of Agrarian Technologies $(P \leq 0.0001)$; UNA $=$ National University of Asuncion $(P<0.0001)$; and smallholder $=$ smallholder farm $(P \leq 0.0001) . \mathrm{A}=$ aerobic control (nonamended, saturated, noncovered); $\mathrm{AN}=$ anaerobic control (nonamended, saturated, plastic covered); $M=$ molasses amended (10.1 Mg/ha); W = wheat bran amended (20.2 Mg/ha); and W+M = wheat bran (20.2 Mg/ha) plus molasses (10.1 Mg/ha) amended. 
ASD: A Promising Tool for Paraguayan Smallholder Farmers for the Sustainable Management of S. sclerotiorum and Potentially Other Soilborne Pathogens

ASD is a soilborne disease management practice that is appropriate for smallholder farmers. In most cases, this technique has been reported to be effective for the control of soilborne pathogens in developed countries such as the United States of America, Japan, the Netherlands, Italy, Spain, the United Kingdom, and Sweden (Guerrero-Díaz and Lacasa-Martinez 2013; McCarty et al. 2014; Momma et al. 2010; Paudel et al. 2018; Runia et al. 2014; Shrestha et al. 2016; Thaning and Gerhardson 2001). Only one study on the efficacy of ASD in South America has been reported, in an Argentinian greenhouse cut flower production system (Yossen et al. 2008). Smallholder farmers in Paraguay, as in other developing countries, have few options for soilborne disease management besides the use of chemical fumigants (Parsa et al. 2014). For this reason, ASD has high potential as a management practice for reduction of $S$. sclerotiorum viable inoculum, being relatively easy and inexpensive for Paraguayan farmers.

During ASD, an increase in soil temperature is observed as a result of the metabolization of carbon sources by soil microorganisms (Achmon et al. 2016). In the present study, mean soil temperatures in ASD-treated soils were significantly higher than in the aerobic control by 1.4 to $2.4^{\circ} \mathrm{C}$. Similarly, during ASD trials in Ohio muck soil (Huron and Stark county), mean soil temperature of ASDtreated plots increased by 1.5 up to $6.3^{\circ} \mathrm{C}$ compared with aerobic control plots (Testen and Miller 2019). For all sites in this study, the mean soil temperatures across treatments ranged from 30 to $32.2^{\circ} \mathrm{C}$. These mean soil temperatures can be considered moderate for ASD according to the classification proposed by Shrestha et al. (2016). In contrast to soil solarization, ASD does not rely on high temperatures to reduce the viability of soilborne pathogens. However, ASD effectiveness decreases at lower temperatures, leading to longer tarping period requirements (Butler et al. 2014).

\section{CETAPAR}

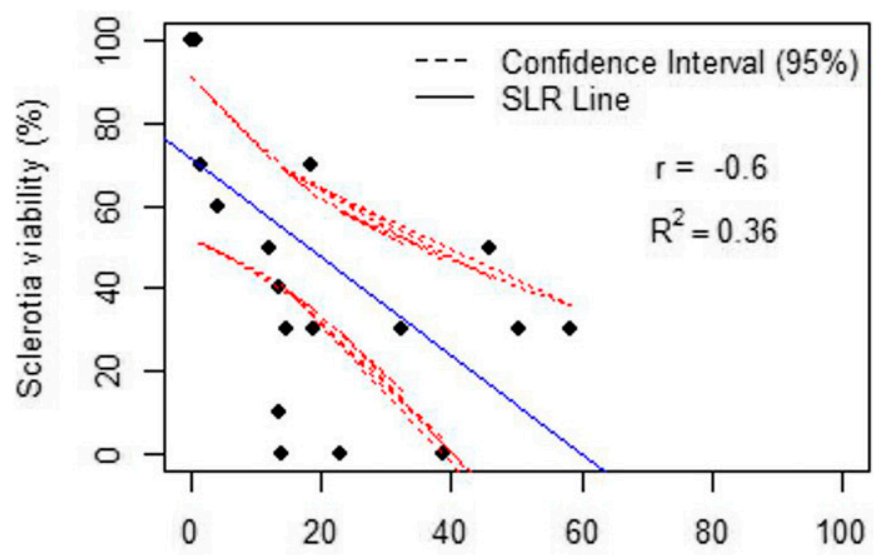

Iris tube paint removed (\%)

\section{IPTA}

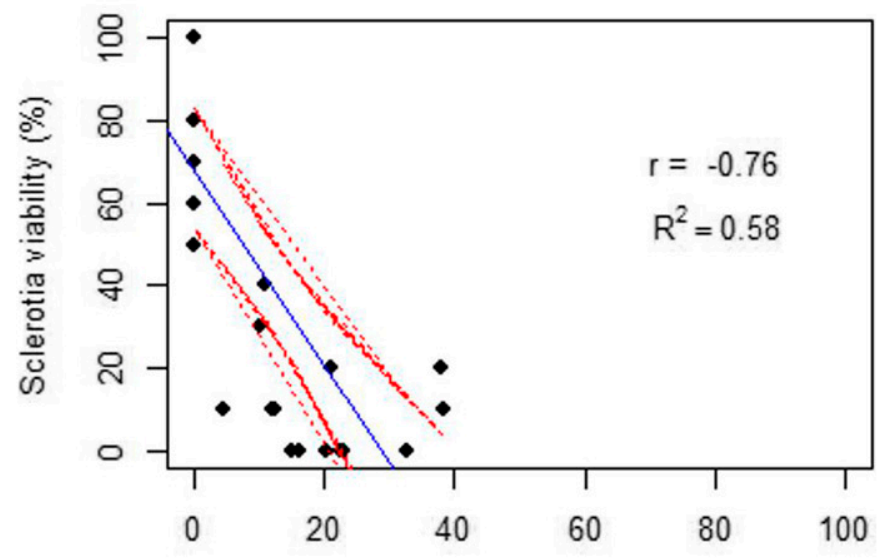

\section{Smallholder}

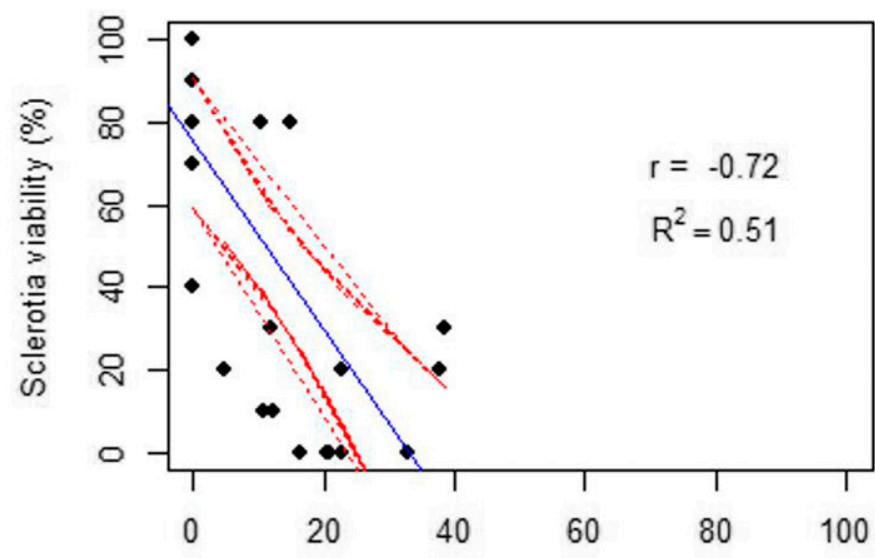

Iris tube paint removed (\%)

\section{UNA}

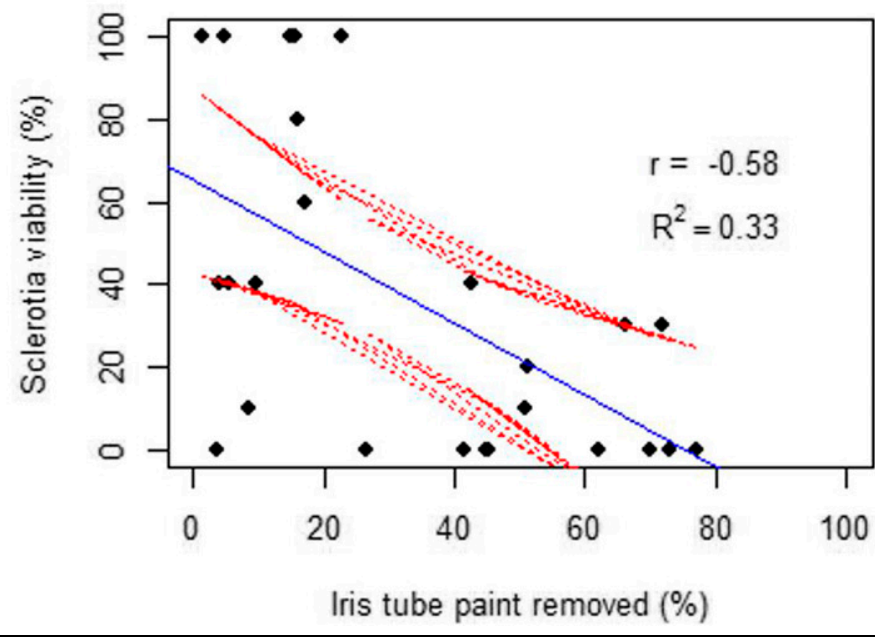

FIGURE 7

Pearson's correlation value $(r)$ for the relation between indicator of reduction in soil (IRIS) paint removed and Sclerotinia sclerotiorum sclerotia viability evaluated in four sites in Paraguay. CETAPAR = Paraguayan Center of Agrarian Technologies $(P=0.0049)$; IPTA = Paraguayan Institute of Agrarian Technologies $(P<0.0001)$; UNA $=$ National University of Asuncion $(P=0.00252)$; and smallholder $=$ smallholder farm $(P=0.0001)$. Higher values for paint removal indicate higher anaerobicity of the soil. 
Higher microbial activity was indicated by higher amounts of $\mathrm{CO}_{2}$ emitted from soils treated with ASD using the combination of wheat bran plus molasses than from aerobic and anaerobic control soils. During the initial phase of ASD, bacterial oxidation of organic matter has the potential to raise the concentration of $\mathrm{CO}_{2}$ within the soil (Achmon et al. 2016). Runia et al. (2014) showed that $\mathrm{CO}_{2}$ concentrations increased with time during ASD treatment, indicating the breakdown of organic matter through microbial activity. High soil $\mathrm{CO}_{2}$ levels reflect the change in microbial biomass, indicating a shift to a bacterial-dominated community (van Agtmaal et al. 2015). It is likely that by combining amendments and increasing amendment rates, specific members of microbial communities could have greater access to utilizable carbon and produce higher amounts of byproducts, such as organic acids and gases deleterious to sclerotia. Runia et al. (2014) developed a "cocktail" of ASD carbon sources called "Herbie." When different soils were treated with "Herbie," higher concentrations of acetic and butyric acids that correlated negatively with the survival of Globodera pallida were observed compared with nontreated soils.

Low oxygen levels (2\%) and high concentrations of carbon dioxide (19\%) have been shown to inhibit the germination of $S$. minor (Imolehin and Grogan 1980). However, the mechanisms of pathogen suppression in ASD are more complex than soil anaerobicity, and other factors such as microbial activity (Mowlick et al. 2013), production of organic acids (Momma et al. 2006) and deleterious gases (Runia et al. 2014), degradation of fungal cell walls by anaerobic bacteria (Ueki et al. 2017), and enhancement of mycoparasitic antagonism (Shrestha et al. 2018; Thaning and Gerhardson 2001) may be involved in reducing sclerotia viability. Although these other factors affecting sclerotia survival were not evaluated during this study, soil anaerobicity is related to these pathogen suppression factors (Shennan et al. 2018). Moreover, increased soil anaerobicity has been linked to higher levels of control of Fusarium oxysporum (Momma et al. 2011), V. dahliae (Shennan et al. 2018), Meloidogyne spp. (Testen and Miller 2018), and $S$. rolfsii (Shrestha et al. 2018).

Sclerotia from molasses-amended ASD-treated soils were not less viable than those from anaerobic control soils at three of four sites. Similarly, ASD using molasses alone did not reduce $R$. solani propagules in the soil compared with the nonamended control (McCarty et al. 2014). Similarly, no significant differences in anaerobic soil conditions were observed between molasses-amended soils compared with nonamended control soils during 2 years of field trials (Butler et al. 2012a). Honma et al. (2012) reported that the application of molasses in paddy soil did not lead to the development of anaerobic conditions owing to its limited percolation. Limited percolation of molasses was observed in our study as well. However, this restraint can be overcome by molasses dilution in water followed by thorough mixing and immediate application (Momma 2008). Also, the rate of molasses applied was half that of wheat bran. It is possible that increasing the rate of molasses may increase pathogen suppression in ASD treatments in which this carbon source is used.

In the present study, wheat bran-amended ASD was as effective in reducing sclerotial survival of $S$. sclerotiorum as the combination of wheat bran plus molasses in all the sites. The use of wheat bran as a carbon source for ASD led to the production of acetic and butyric acids up to 2,000 and $1,900 \mathrm{mg} / \mathrm{kg}$ of dry soil, respectively, concentrations that were deleterious to Ralstonia solanacearum and F. oxysporum f. sp. lycopersici (Momma et al. 2006). Moreover, the incidence of Fusarium wilt (caused by $F$. oxysporum) in a carnation crop was significantly reduced (by 84 to 97\%) in ASD-treated soils using wheat bran as an amendment (Yossen et al. 2008).
Likewise, soil populations of $V$. dahliae were significantly reduced by wheat bran-based ASD treatments during bioassays (Testen and Miller 2018).

Although wheat bran alone and wheat bran plus molasses were equally effective in ASD for reducing viability of S. sclerotiorum sclerotia, it may be advantageous to use the combination to improve overall suppression of a range of soilborne pathogens (Katase et al. 2009; Momma et al. 2006; Mowlick et al. 2012; Shrestha et al. 2018; Yossen et al. 2008). These organic amendments are inexpensive and readily available to Paraguayan farmers. Wheat is broadly cultivated and processed in Paraguay, and wheat bran is a byproduct of milling whole grains (Alegre 2017). Similarly, molasses is a byproduct obtained from the processing of sugarcane, which is also widely grown in Paraguay (Hira and Torres-Garcete 2011). Even though these organic amendments are relatively inexpensive, costs related to transportation and labor could potentially increase ASD costs. Ideally, in order to reduce costs, cover crops could be grown and incorporated into the soil as potential carbon sources for ASD (Butler et al. 2012b). However, more research is needed on optimum carbon source rates, tarping period, and plastic covers before farmers are likely to adopt ASD as a common practice in Paraguay.

In summary, ASD reduced the viability of sclerotia of $S$. sclerotiorum after 3 weeks of treatment in different soil types and environments in Paraguay. Differences between carbon source effectiveness to reduce sclerotia survival were observed in two out of four sites. More research will be required to achieve the same effectiveness regardless of potential differences in sites. Future work should examine different rates and carbon source combinations and their effect on different pathogens (bacteria, plant parasitic nematodes, and oomycetes), considering various depths of disinfestation. The use of on-farm trials can help in disseminating this technology to farmers in Paraguay and in other South American countries. In addition, an evaluation of the economic impact of this management tool on crop profitability considering the time and inputs necessary in each region will be necessary to promote adoption of ASD by smallholder farmers.

\section{Acknowledgments}

We thank our farmer collaborator Concepcion Morai; Fatima Rios and Hassan Bittar from UNA; Monica Bogado, Jorge Dominguez, Lorena Marini, and Ingo Kliewer from CETAPAR; and Juan Carlos Cousiño, Vilma Gimenez, Gregorio Bozzano, and Gloria Montiel from IPTA for arranging field trials in the different research institutions.

\section{Literature Cited}

Abawi, G., and Grogan, R. 1979. Epidemiology of diseases caused by Sclerotinia species. Phytopathology 69:899-904.

Achmon, Y., Harrold, D. R., Claypool, J. T., Stapleton, J. J., VanderGheynst, J. S., and Simmons, C. W. 2016. Assessment of tomato and wine processing solid wastes as soil amendments for biosolarization. Waste Manag. 48: 156-164.

Alegre, C. E. H. 2017. Eficiencia de comercialización de semillas de trigo en el Paraguay. Master's thesis, Universidade Federal de Pelotas, Brazil.

Amado, T. J. C., and Eltz, F. L. F. 2008. Nitrogen management in Southern Brazil and Western Paraguay. Pages 124-143 in: Nitrogen in the Environment. Elsevier, London, U.K.

Arrúa, A., and Aquino, A. 2013. Effect of solarization on sclerotia of Sclerotinia sclerotiorum (Lib.) de Bary, and the fluctuation of the population of nematodes present in the soil. Invest. Agrar. 7:5-11.

Bardin, S., and Huang, H. 2001. Research on biology and control of Sclerotinia diseases in Canada. Can. J. Plant Pathol. 23:88-98.

Ben-Yephet, Y. 1988. Control of sclerotia and apothecia of Sclerotinia sclerotiorum by metham-sodium, methyl bromide and soil solarization. Crop Prot. 7:25-27. 
Ben-Yephet, Y., Genizi, A., and Siti, E. 1993. Sclerotial survival and apothecial production by Sclerotinia sclerotiorum following outbreaks of lettuce drop. Phytopathology 83:509-513.

Blok, W. J., Lamers, J. G., Termorshuizen, A. J., and Bollen, G. J. 2000. Control of soilborne plant pathogens by incorporating fresh organic amendments followed by tarping. Phytopathology 90:253-259.

Butler, D. M., Kokalis-Burelle, N., Muramoto, J., Shennan, C., McCollum, T. G., and Rosskopf, E. N. 2012a. Impact of anaerobic soil disinfestation combined with soil solarization on plant-parasitic nematodes and introduced inoculum of soilborne plant pathogens in raised-bed vegetable production. Crop Prot. 39:33-40.

Butler, D. M., Ownley, B. H., Dee, M. E., Eichler Inwood, S. E., McCarty, D. G., Shrestha, U., Kokalis-Burelle, N., and Rosskopf, E. N. 2014. Low carbon amendment rates during anaerobic soil disinfestation (ASD) at moderate soil temperatures do not decrease viability of Sclerotinia sclerotiorum sclerotia or Fusarium root rot of common bean. Acta Hortic.: 203-208.

Butler, D. M., Rosskopf, E. N., Kokalis-Burelle, N., Albano, J. P., Muramoto, J., and Shennan, C. 2012b. Exploring warm-season cover crops as carbon sources for anaerobic soil disinfestation (ASD). Plant Soil 355: 149-165.

Castenson, K. L., and Rabenhorst, M. C. 2006. Indicator of reduction in soil (IRIS). Soil Sci. Soc. Am. J. 70:1222-1226.

de Mendiburu, F. 2015. Package 'agricolae.' R Package, version 1.2-3.

Durman, S. B., Menéndez, A. B., and Godeas, A. M. 2003. Mycelial compatibility groups in Buenos Aires field populations of Sclerotinia sclerotiorum (Sclerotiniaceae). Aust. J. Bot. 51:421-427.

Fernando, W. G. D., Nakkeeran, S., and Zhang, Y. 2004. Ecofriendly methods in combating Sclerotinia sclerotiorum (Lib.) de Bary. Res. Signpost 661: 329-347.

Goud, J. K. C., Termorshuizen, A. J., Blok, W. J., and van Bruggen, A. H. C. 2004. Long-term effect of biological soil disinfestation on Verticillium wilt. Plant Dis. 88:688-694.

Guerrero-Díaz, M., and Lacasa-Martinez, C. 2013. Evaluation of repeated biodisinfestation using Brassica carinata pellets to control Meloidogyne incognita in protected pepper crops. Span. J. Agric. Res. 11:485-493.

Hamada, Y., and Tanaka, T. 2001. Dynamics of carbon dioxide in soil profiles based on long-term field observation. Hydrol. Processes 15: $1829-1845$

Hao, J. J., and Subbarao, K. V. 2005. Comparative analyses of lettuce drop epidemics caused by Sclerotinia minor and S. sclerotiorum. Plant Dis. 89: 717-725.

Hira, A., and Torres-Garcete, P. 2011. Can biofuels be an engine for growth in small developing economies-The case of Paraguay. Pages 105-128 in: Economic Effects of Biofuel Production. M. A. dos Santos Bernardes, ed. IntechOpen, London, U.K.

Honma, T., Kaneko, A., Ohba, H., and Ohyama, T. 2012. Effect of application of molasses to paddy soil on the concentration of cadmium and arsenic in rice grain. Soil Sci. Plant Nutr. 58:255-260.

Huang, X., Liu, L., Wen, T., Zhang, J., Shen, Q., and Cai, Z. 2016a. Reductive soil disinfestations combined or not with Trichoderma for the treatment of a degraded and Rhizoctonia solani infested greenhouse soil. Sci. Hortic. (Amsterdam) 206:51-61

Huang, X., Liu, L., Wen, T., Zhang, J., Wang, F., and Cai, Z. 2016b. Changes in the soil microbial community after reductive soil disinfestation and cucumber seedling cultivation. Appl. Microbiol. Biotechnol. 100:5581-5593.

Imolehin, E. D., and Grogan, R. G. 1980. Effects of oxygen, carbon dioxide, and ethylene on growth, sclerotial production, germination, and infection by Sclerotinia minor. Phytopathology 70:1158-1161.

Insaurralde, L., Sanabria Velazquez, A., Verdina, D., Sotelo, P., and Barúa, J. 2017. Isolation and characterization of native Trichoderma spp. and phytopathogenic fungi in Paraguay. Pages 1071-1074 in: IV Congreso Nacional de Ciencias Agrarias. FCA/UNA, ed. FCA/UNA, Asunción, Paraguay.

Katase, M., Kubo, C., Ushio, S., Ootsuka, E., Takeuchi, T., and Mizukubo, T. 2009. Nematicidal activity of volatile fatty acids generated from wheat bran in reductive soil disinfestation. Jpn. J. Nematol. 39:53-62.

Kawasaki, V. H., and Machado, C. 2013. Establishment of a semi-selective method for the detection of Sclerotinia sclerotiorum in dry bean and soybean seeds. J. Seed Sci. 35:435-442.

Kohli, Y., Brunner, L. J., Yoell, H., Milgroom, M. G., Anderson, J. B., Morrall, R. A. A., and Kohn, L. M. 1995. Clonal dispersal and spatial mixing in populations of the plant pathogenic fungus Sclerotinia sclerotiorum. Mol. Ecol. 4:69-77.

Lobo, M., Jnr., Lopes, C. A., and Silva, W. L. C. 2000. Sclerotinia rot losses in processing tomatoes grown under centre pivot irrigation in central Brazil. Plant Pathol. 49:51-56.
Matheron, M. E., and Porchas, M. 2005. Influence of soil temperature and moisture on eruptive germination and viability of sclerotia of Sclerotinia minor and S. sclerotiorum. Plant Dis. 89:50-54.

McCarty, D. G., Eichler Inwood, S. E., Ownley, B. H., Sams, C. E., Wszelaki, A. L., and Butler, D. M. 2014. Field evaluation of carbon sources for anaerobic soil disinfestation in tomato and bell pepper production in Tennessee. HortScience 49:272-280.

Momma, N. 2008. Biological soil disinfestation (BSD) of soil borne pathogens and its possible mechanisms. Jpn. Agric. Res. Q. 42:7-12.

Momma, N., Kobara, Y., and Momma, M. 2011. $\mathrm{Fe}^{2+}$ and $\mathrm{Mn}^{2+}$, potential agents to induce suppression of Fusarium oxysporum for biological soil disinfestation. J. Gen. Plant Pathol. 77:331-335.

Momma, N., Kobara, Y., Uematsu, S., Kita, N., and Shinmura, A. 2013. Development of biological soil disinfestations in Japan. Appl. Microbiol. Biotechnol. 97:3801-3809.

Momma, N., Momma, M., and Kobara, Y. 2010. Biological soil disinfestation using ethanol: Effect on Fusarium oxysporum f. sp. lycopersici and soil microorganisms. J. Gen. Plant Pathol. 76:336-344.

Momma, N., Yamamoto, K., Simandi, P., and Shishido, M. 2006. Role of organic acids in the mechanisms of biological soil disinfestation (BSD). J. Gen. Plant Pathol. 72:247-252.

Mowlick, S., Hirota, K., Takehara, T., Kaku, N., Ueki, K., and Ueki, A. 2012. Development of anaerobic bacterial community consisted of diverse clostridial species during biological soil disinfestation amended with plant biomass. Soil Sci. Plant Nutr. 58:273-287.

Mowlick, S., Inoue, T., Takehara, T., Kaku, N., Ueki, K., and Ueki, A. 2013. Changes and recovery of soil bacterial communities influenced by biological soil disinfestation as compared with chloropicrin-treatment. AMB Express 3:46.

Parsa, S., Morse, S., Bonifacio, A., Chancellor, T. C. B., Condori, B., Crespo-Perez, V., Hobbs, S. L. A., Kroschel, J., Ba, M. N., Rebaudo, F., Sherwood, S. G., Vanek, S. J., Faye, E., Herrera, M. A., and Dangles, O. 2014. Obstacles to integrated pest management adoption in developing countries. Proc. Natl. Acad. Sci. 111:3889-3894.

Patterson, C. L., and Grogan, R. G. 1985. Differences in epidemiology and control of lettuce drop caused by Sclerotinia minor and S. sclerotiorum. Plant Dis. 69:766-770.

Paudel, B. R., Di Gioia, F., Zhao, X., Ozores-Hampton, M., Hong, J. C., KokalisBurelle, N., Pisani, C., and Rosskopf, E. N. 2018. Evaluating anaerobic soil disinfestation and other biological soil management strategies for open-field tomato production in Florida. Renewable Agric. Food Syst.: 1-12.

R Core Team. 2018. R: A Language and Environment for Statistical Computing. R Foundation for Statistical Computing, Vienna, Austria. https://www. r-project.org/

Rabenhorst, M. C. 2010. Visual assessment of IRIS tubes in field testing for soil reduction. Wetlands 30:847-852.

Rosskopf, E. N., Burelle, N., Hong, J., Butler, D. M., Noling, J. W., He, Z., Booker, B., and Sances, F. 2014. Comparison of anaerobic soil disinfestation and drip-applied organic acids for raised-bed specialty crop production in Florida. Acta Hortic. 1044:221-228.

Runia, W. T., Thoden, T. C., Molendijk, L. P. G., Van Den Berg, W., Streminska, M. A., Van Der Wurff, A. W. G., Termorshuizen, A. J., Feil, H., and Meints, H. 2014. Unravelling the mechanism of pathogen inactivation during anaerobic soil disinfestation. Acta Hortic. 1044:177-193.

Shennan, C., Muramoto, J., Koike, S., Baird, G., Fennimore, S., Samtani, J., Bolda, M., Dara, S., Daugovish, O., Lazarovits, G., Butler, D., Rosskopf, E., Kokalis-Burelle, N., Klonsky, K., and Mazzola, M. 2018. Anaerobic soil disinfestation is an alternative to soil fumigation for control of some soilborne pathogens in strawberry production. Plant Pathol. 67:51-66.

Shrestha, U., Augé, R. M., and Butler, D. M. 2016. A meta-analysis of the impact of anaerobic soil disinfestation on pest suppression and yield of horticultural crops. Front. Plant Sci. 7:1-20.

Shrestha, U., Dee, M. E., Ownley, B. H., and Butler, D. M. 2018. Anaerobic soil disinfestation reduces germination and affects colonization of Sclerotium rolfsii sclerotia. Phytopathology 108:342-351.

Stevenson, M., Nunes, T., Heuer, C., Marshall, J., Sanchez, J., Thornton, R., Reiczigel, J., Robison-Cox, J., Sebastiani, P., Solymos, P., Yoshida, K., and Firestone, S. 2015. Package "epiR". Tools for the analysis of epidemiological data $\mathrm{R}$ package version 0.9-62. CRAN.R-project.org.

Subbarao, K. V. 1998. Progress toward integrated management of lettuce drop. Plant Dis. 82:1068-1078.

Testen, A. L., and Miller, S. A. 2018. Carbon source and soil origin shape soil microbiomes and tomato soilborne pathogen populations during anaerobic soil disinfestation. Phytobiomes 2:138-150.

Testen, A. L., and Miller, S. A. 2019. Anaerobic soil disinfestation to manage soilborne diseases in muck soil vegetable production systems. Plant Dis. 103. doi: 10.1094/PDIS-09-18-1578-RE. 
Thaning, C., and Gerhardson, B. 2001. Reduced sclerotial soil-longevity by wholecrop amendment and plastic covering. J. Plant Dis. Prot. 108:143-151.

Ueki, A., Takehara, T., Ishioka, G., Kaku, N., and Ueki, K. 2017. Degradation of the fungal cell wall by clostridial strains isolated from soil subjected to biological soil disinfestation and biocontrol of Fusarium wilt disease of spinach. Appl. Microbiol. Biotechnol. 101:8267-8277.

van Agtmaal, M., van Os, G. J., Gera Hol, W. H., Hundscheid, M. P. J., Runia, W. T., Hordijk, C. A., and de Boer, W. 2015. Legacy effects of anaerobic soil disinfestation on soil bacterial community composition and production of pathogen-suppressing volatiles. Front. Microbiol. 6:1-12.
Wei, F., Passey, T., and Xu, X. 2016. Effects of individual and combined use of bio-fumigation-derived products on the viability of Verticillium dahliae microsclerotia in soil. Crop Prot. 79:170-176.

Wrather, J. A., Anderson, T. R., Arsyad, D. M., Gai, J., Ploper, L. D., PortaPuglia, A., Ram, H. H., and Yorinori, J. T. 1997. Soybean disease loss estimates for the top 10 soybean producing countries in 1994. Plant Dis. 81: 107-110.

Yossen, V., Zumelzu, G., Gasoni, L., and Kobayashi, K. 2008. Effect of soil reductive sterilization on Fusarium wilt in greenhouse carnation in Córdoba, Argentina. Australas. Plant Pathol. 37:520-522. 